\title{
Editorial for the VEESD 2013 special issue
}

\author{
Christoph Adam • Rudolf Heuer
}

Received: 27 January 2015/Accepted: 7 February 2015/Published online: 15 February 2015

(C) Springer Science+Business Media Dordrecht 2015

The Vienna Congress on Earthquake Engineering and Structural Dynamics, VEESD 2013, took place in August 2013 at the Vienna University of Technology, which is located in the Center of Vienna. This congress aimed at fostering scientific interaction among the vast community of researchers contributing to earthquake engineering, seismology, and structural dynamics in a broad sense. About 400 participants from all over the world delivering about 270 presentations of the latest achievements in these fields made this scientific event a great success.

We are proud to present the VEESD 2013 special issue in the Bulletin of Earthquake Engineering. It comprises 13 contributions, which were selected on the basis of the response and feedback of both mini-symposium organizers and participants. The papers of this special issue provide new insight into the state-of-the-art of different fields in earthquake engineering based on experimental, analytical, and numerical studies as well as field observations after earthquakes, as it becomes obvious from the subsequent short summary.

The first paper by Weatherill et al. (2015) illustrates the effect of the spatial variability of earthquake ground motions upon the resulting seismic loss of aggregated portfolios of heterogeneous building typologies. Iervolino et al. (2015) present a model on life-cycle assessment considering the effect of damaging aftershocks. Using a probabilistic simulation-based framework Gidaris and Taflanidis (2015) assess the performance and optimal design of fluid viscous dampers through lifecycle criteria. Tasligedik et al. (2015) propose low damage solutions for non-structural drywall partitions capable of reaching high levels of drift without loss of serviceability. Penna (2015) discusses in his contribution several aspects of the seismic response and capacity of stone masonry buildings. By the evaluation of experimental results Petry and Beyer (2015) address the horizontal in-plane

C. Adam (ه)

Unit of Applied Mechanics, University of Innsbruck, Technikerstr. 13, 6020 Innsbruck, Austria

e-mail: christoph.adam@uibk.ac.at

R. Heuer

Vienna University of Technology, Karlsplatz 13/E2063, 1040 Vienna, Austria 
displacement behavior of modern clay brick masonry. Elkady and Lignos (2015) investigate the cyclic behavior of deep wide-flange sections, used as columns in steel Special Moment Frames, through detailed finite element (FE) analysis. The study of Alarcon et al. (2015) aims at correlating global and design parameters of reinforced concrete (RC) structural walls with damage observed after the 2010 Chile earthquake. Schwarz et al. (2015) evaluate in their study the EMS-98 guidelines for vulnerability and damage assessment. De Luca et al. (2015) use a damage data database of $131 \mathrm{RC}$ buildings damaged during the 2009 L'Aquila (Italy) earthquake to evaluate observational fragility curves. Based on these outcomes they calibrate an analytical spectral based approach (FAST), meant for the estimate of fragility curves of infilled RC buildings up to heavy damage according to EMS-98. Jalayer et al. (2015) present a Bayesian approach on the Cloud Analysis to take into account both record-to-record variability and other sources of uncertainty related to structural modeling. The study of Tsantaki et al. (2015) assesses the effect of parameter uncertainty of non-deteriorating P-delta vulnerable single-degree-offreedom systems on the median and dispersion of the collapse capacity. In the last contribution of Lopez et al. (2015) an innovative displacement based seismic design procedure for P-Delta sensitive framed structures considering sidesway collapse prevention is presented.

We would like to thank all the authors, who have accepted our invitation to contribute to this special issue, the mini-symposium organizers for their support, and the reviewers for their thorough and valuable comments to these studies. Our special thanks goes to Professor Attila Ansal, Main Editor, for providing us with the opportunity of publishing this special issue in the Bulletin of Earthquake Engineering and for his guidance during the evolution process. We gratefully acknowledge the continuous assistance of Petra D. van Steenbergen and Cynthia Clement from Springer, who always responded to our queries in an efficient and timely manner.

Guest Editors.

\section{References}

Alarcon C, Hube M, Jünemann R, de la Llera JC (2015) Characteristics and displacement capacity of Reinforced concrete walls in damaged buildings during 2010 Chile earthquake. Bull Earthq Eng. doi:10.1007/s10518-015-9727-0

De Luca F, Verderame GM, Manfredi G (2015) Analytical versus observational fragilities: the case of Pettino (L'Aquila) damage data database. Bull Earthq Eng. doi:10.1007/s10518-014-9658-1

Elkady A, Lignos D (2015) Analytical investigation of the cyclic behavior and plastic hinge formation in deep wide-flange steel beam-columns. Bull Earthq Eng. doi:10.1007/s10518-014-9640-y

Gidaris I, Taflanidis AA (2015) Performance assessment and optimization of fluid viscous dampers through life-cycle cost criteria and comparison to alternative design approaches. Bull Earthq Eng. doi:10.1007/ s10518-014-9646-5

Iervolino I, Giorgio M, Polidoro B (2015) Reliability of structures to earthquake clusters. Bull Earthq Eng. doi:10.1007/s10518-014-9679-9

Jalayer F, De Risi R, Manfredi G (2015) Bayesian Cloud Analysis: efficient structural fragility assessment using linear regression. Bull Earthq Eng. doi:10.1007/s10518-014-9692-z

Lopez S, Adam C, Ayala G (2015) A novel displacement-based seismic design method for framed structures considering P-Delta induced dynamic instability. Bull Earthq Eng. doi:10.1007/s10518-014-9688-8

Penna A (2015) Seismic assessment of existing and strengthened stone-masonry buildings: critical issues and possible strategies. Bull Earthq Eng. doi:10.1007/s10518-014-9659-0

Petry S, Beyer K (2015) Limit states of modern unreinforced clay brick masonry walls subjected to in-plane loading. Bull Earthq Eng. doi:10.1007/s10518-014-9695-9 
Schwarz J, Abrahamczyk L, Leipold M, Wenk T (2015) Vulnerability assessment and damage description for R.C. frame structures following the EMS-98 principles. Bull Earthq Eng. doi:10.1007/s10518-0149694-x

Tasligedik AS, Pampanin S, Palermo A (2015) Low damage seismic solutions for non-structural drywall partitions. Bull Earthq Eng. doi:10.1007/s10518-014-9654-5

Tsantaki S, Ibarra LF, Adam C (2015) Effect of P-delta uncertainty on the seismic collapse capacity and its variability of single-degree-of freedom systems. Bull Earthq Eng. doi:10.1007/s10518-014-9687-9

Weatherill G, Silva V, Crowley H, Bazzurro P (2015) Exploring the impact of spatial correlations and uncertainties for portfolio analysis in probabilistic seismic loss estimation. Bull Earthq Eng. doi:10. 1007/s10518-015-9730-5 